\title{
Implementation of Worker Rights Protection for Government Employees with Employment Agreements
}

\author{
Asianto Nugroho ${ }^{1}$, Reza Octavia Kusumaningtyas ${ }^{2}$, Ravi Danendra ${ }^{3}$, Gusti Faza Aliya ${ }^{4}$ Fatma Ulfatun Najicha ${ }^{5}$ \\ 1.2.3.4.5 Universitas Sebelas Maret \\ Surakarta, Indonesia \\ asiantonugroho@staff.uns.ac.id
}

\begin{abstract}
This research aims to analyze the protection of workers' rights for Government Employees with Employment Agreements (PPPK). The research method used is normative juridical research, which is a study that focuses on the study of literature in the form of reading, studying, and analyzing legal materials. The data obtained by the literature study method comes from the study of documents analyzed qualitatively juridically. The study results showed that the implementation of the fulfillment of the rights, obligations, and regulations of Government Employees with Employment Agreements (PPPK) appointment still requires a review of the clarity in the arrangement. Decree of Government Employees with Employment Agreements (PPPK) that is not by human rights principles should not occur. Respect for a person's right to protection for their work is essential in Indonesian Law.
\end{abstract}

Keywords- Position, Protection, Rights, Government Employees with Employment Agreements.

\section{INTRODUCTION}

Non-permanent employees are designate for everyone recruited directly and employed in a particular agency with a specific or limited period. [1] Non-permanent officers domiciled as auxiliary officers in carrying out the State Civil Apparatus (ASN) duties. Discretion taken by government officials in the appointment of non-permanent employees/honorees/ contracts aims to meet the needs of the number of urgent employees so that the implementation of government functions can run well.[2]

After the birth of Law No. 5 of 2014 on the State Civil Apparatus (ASN), it no longer became known related to the term honoree but was replaced with Government Employees with Employment Agreements (PPPK). [3]Law related to the State Civil Apparatus (ASN) is a law of Law resulting from reforms to the previous Law on Civil Servants. Law of the Republic of Indonesia Number 8 of 1947 on Staffing Points is a Law that has updated the Law of the Republic of Indonesia Number 18 of 1961 on The Basic Provisions of Staffing.[4] A State Civil Apparatus Law is needed to realize bureaucratic reform, namely the State Law of the Republic of Indonesia Number 5 of 2014 concerning the State Civil Apparatus, called the State Civil Apparatus (ASN) Law. The existence of Government Employees with Employment Agreements (PPPK) in the State Civil Apparatus (ASN) Act becomes an exciting thing because Law No. 8 of 1974 on Staffing has not regulated related Government Employees with Employment Agreements (PPPK).[5]
Related to the arrangement of employment agreements for employees of the central and regional governments has not been regulated in the Law on Staffing. The State Civil Apparatus (ASN) Law Article 6 states that the State Civil Apparatus (ASN) employees consist of civil servants and Government Employees with Employment Agreements (PPPK). Government Employees with Employment Agreements (PPPK) in the Indonesian Government apparatus is lifted based on the employment agreement within a certain period. Government Employees with Employment Agreements (PPPK) are Indonesian citizens qualified to carry out government duties.[6]

UU-ASN regulates the rights owned by Government Employees with Employment Agreements (PPPK) in the form of the right to get salaries and benefits, leave, protection, and competency development held once a year. However, there is still uncertainty about the legal status of people who are status as contract employees in existing laws and regulations and arrangements for legal protection for Government Employees with Work Protection. Therefore, a problem is raised, namely related to how the position and protection of the rights of Government Employees with Employment Agreements.[7]

\section{RESEARCH METHOD}

The research method that the author uses is juridically normative research. Normative juridical research is a study that focuses on the study of literature in the form of reading, studying and analyzing legal materials. The data obtained by the literature study method comes from the study of documents analyzed qualitatively juridically. Then, the author uses analytical descriptive to analyze data based on systematic rules to overview the problems raised in this authorship.[8]

\section{FINDINGS AND DISCUSSION}

Regulations related to Government Employees with Employment Agreements (PPPK) have been listened to in Law No. 5 of 2014 on State Civil Apparatus (ASN) and Government Regulation No. 49 of 2018 on Management of Government Employees with Employment Agreements (PPPK). The position of Government Employees with Employment Agreements as elements of the State Civil Apparatus (ASN) should be to implement the policies set by agency leaders and should not be influenced by intervention from all political groups and parties. [9]

The legal relationship between the two is the difference some of the differentiators lie in the rights, status, and sustainability of work. According to the Law on the State 
Civil Apparatus (ASN), Government Employees with Employment Agreements (PPPK) will not be appointed as a State Civil Apparatus (ASN) candidate unless they register as a State Civil Apparatus (ASN) candidate and follows the selection stage.[10]

Government Employees with Employment Agreements (PPPK) is the result of the spirit of bureaucratic reform. That is because its recruitment is base on merit and professionalism systems and has a better career path than honorees. Although existing regulations state that Government Employees with Employment Agreements (PPPK) have the same position as the State Civil Apparatus (ASN), but there are still provisions that are not by the fulfillment of the rights that Government Employees should obtain with Employment Agreements (PPPK). Government Employees with Employment Agreements (PPPK) recruitment is carried out as one form of government anticipation of the high number of employee needs but still pay attention to the funds available from the STATE BUDGET / APBD. The recruitment aims to increase the base of professionalism and competence of bureaucratic implementation.[11]

Through the Government is the stakeholder, the state should guarantee accountability for the fulfillment of the rights of each worker. The distinction of status between the State Civil Apparatus (ASN) and Government Employees with Employment Agreements (PPPK) is not a problem if the distinction does not have consequences for the distinction of rights.[12]

States must create equality and ensure active and positive non-discriminatory treatment. States have obligations to implement fundamental values of economic, social, and cultural rights in the field of work, such as ensuring independence for workers, in this case, a treatment that is equal and non-discriminatory and ensures the security of the sustainability of each worker. The different treatment between the State Civil Apparatus (ASN) and Government Employees with Employment Agreements (PPPK) in the system of working life and granting rights can lead to conditions that do not meet the principle of equal and non-discriminatory in the principle of human rights.[13]

Provisions related to Government Employees with Employment Agreements (PPPK) guarantee the same job opportunity as the State Civil Apparatus (ASN). However, the working period system that applies to Government Employees with Employment Agreements (PPPK) cannot guarantee the same opportunity as the State Civil Apparatus (ASN) to achieve the highest position. When viewed from the principle of fundamental economic, social, and cultural rights values, the state has not fully presently fulfilled the worker suitable for its work. The use of human rights principles to conduct a review of Government Employees with Employment Agreements (PPPK) regulations is an effort by the state to consolidate management regulations by respecting workers' rights to workers as stipulated in existing regulations.[14]

When referring to the State Civil Apparatus (ASN), Law and PP Government Employees with Employment Agreements (PPPK) Management, Government
Employees with Employment Agreements (PPPK) management is not familiar with career development, promotion, and promotion. Of course, this shows that a person can contract for the same job for life. The worker's inequality of rights and opportunities is one example of the violation of the principle of justice and equality.[15]

The State Civil Apparatus (ASN) gets pension protection facilities, while Government Employees with Employment Agreements (PPPK) do not get such facilities. Then, regarding the time of filling the position, there is a difference between the two. Government Employees with Employment Agreements (PPPK) only fill positions according to the contract term agreed through specific employment contracts. Provisions related to the State Civil Apparatus (ASN) position are regulating in-laws and regulations with all their duties and obligations. While Government Employees with Employment Agreements (PPPK) career development only serves as control over worker performance to be considered in terms of the contract renewal.[16]

Article 69 of the ASN Act states as follows civil servant career development is carried out based on competencies, performance assessments, qualifications, and needs of Government Agencies. Career development of civil servants' integrity and morality. Competence, as referred to in paragraph (1), includes: Meanwhile, in the context of Government Employees with Employment Agreements (PPPK), there are differences. Article 102 of UU-ASN states.[17]

There must be a precise mechanism related to the appointment process, the difference in obligations between Government Employees with Employment Agreements (PPPK) and the State Civil Apparatus (ASN), and positions that Government Employees can fill with Employment Agreements (PPPK). The protection of workers' rights is specific aim at developing labor and improving worker performance. The development of labor intends to improve workers' quality and participation in development and expand the protection of workers and their families to promote human dignity. It is expected for the Government to make more specific and detailed implementing regulations to provide clarity on the rights obtained by Government Employees with Employment Agreements (PPPK) and still respect the human rights that each individual owns.[18]

\section{IV.CONCLUSION}

Based on the concept, the legal status between the State Civil Apparatus (ASN) and Government Employees with Employment Agreements (PPPK) is different. The State Civil Apparatus (ASN) has legal power in policymaking according to its authority. While Government Employees with Employment Agreements (PPPK) is a government employee with specific skills tasked with helping implement the State Civil Apparatus (ASN) duties. This difference must be regulated what form of protection of the rights that have so that there is no conflict. The implementation of the protection of worker rights for Government Employees with a Work Agreement (PPPK) 
considers being still lacking. That evidence by the many different rights and opportunities that each worker has. It should be in the legislation to provide firmness for protecting rights obtained for Government Employees with Employment Agreements (PPPK).

\section{REFERENCES}

[1] Purwoko and A. P, "Tinjauan Literatur sebagai Perbandingan dengan Praktek pada Organisasi Publik di Indonesia," J. Kebijak. dan Manaj. PNS, vol. 7, no. 2, p. 12, 2013.

[2] L. C. Lintang, Adriano Martufi, and J.W. Ouwerker, "The Alternative Concepts of Blasphemy Law in Indonesia: Legal Comparison with Ireland and Canada," Bestuur, vol. 8, no. 2, pp. 121-128, 2020.

[3] R. U. Malwa, "Evaluasi Pelaksanaan UndangUndang Nomor 5 Tahun 2014 tentang Aparatur Sipil Negara (ASN) ( Studi Kasus : Pasal 22 tentang Hak PPPK ) di Kantor Satuan Polisi Pamong Praja)," $J$. Pemerintah. dan Polit. Glob., vol. 04, no. 02, pp. 4649, 2019.

[4] A. A. Herman and M. J. Hayat, "Management of High Secondary Education After Regional Government Law," J. Hum. Rights, Cult. Leg. Syst., vol. 1, no. 2, pp. 395-396, 2021.

[5] M. Pungky and H. Wijaya, "Legislation Impediments in Reorganising Government Bodies in Indonesia," Bestuur, vol. 9, no. 1, pp. 1-16, 2021.

[6] S. R. Novikasari, D. Q. Ly, and K. Gershaneck, "Taxing Micro, Small and Medium Enterprises in Yogyakarta: Regulation and Compliance," Bestuur, vol. 9, no. 1, 2021.

[7] Saidah Fasihah Binti Che Yussoff and R. Nordin, "Freedom of Expression in Malaysia: Compatibility with the International Human Rights Standard Saidah," Bestuur, vol. 9, no. 1, pp. 44-59, 2021.

[8] L. Karjoko, Z. N. Rosidah, and I. G. A. K. R. Handayani, "Refleksi Paradigma Ilmu Pengetahuan Bagi Pembangunan Hukum Pengadaan Tanah Lego," Bestuur, vol. 7, no. 2, pp. 1-14, 2019.

[9] R. Danendra, I. G. Ayu, K. Rachmi, and A. K. Jaelani, "Legal Protection of Non Wage Workers Rights After Omnibus Law," Jurisprudentie, vol. 8, no. 13, pp. 8599, 2021.

[10] N. P. Hidayah, "The Implementation of Labor Development Principles According to Job Creation Law as a Reason to Protect Wages Rights," Bestuur, vol. 8, no. 2, pp. 121-128, 2020.

[11] S. Fahmi, A. Faridhi, and N. Hendayana, "Pelaksanaan Undnag-undang Nomor 5 Tahun 2014 tentang Aparatur Sipil Negara terhadap PPPK yang dilakukan di SMP Negeri 15 pekanbaru," J. Huk. Respublica, pp. 1-15, 2021.

[12] W. B. Putri et al., "Medicolegal Perspective on Physician-Induced Demand Issue," Bestuur, vol. 9, no. 1, pp. 106-124, 2021.

[13] D. E. Wibowo, "Ewuh Pakewuh Cultural Reconstruction to Equal Consumer Protection," $J$. Best., vol. 8, no. 1, pp. 1-8, 2020.
[14] F. Tobroni, "TINJAUAN HAM DALAM REGULASI PPPK DENGAN INTERTEKSTUALITAS TEKS HUKUM ( Human Rights Review in Regulations on PPPK with Intertextuality Legal Text )," J. HAM, vol. 11, no. 2, pp. 4-8, 2020.

[15] N. Ishak, R. R. Hasibuan, and T. S. Arbani, "Bureaucratic and Political Collaboration Towards a Good Governance System," Bestuur, vol. 8, no. 1, p. 19, 2020.

[16] I. G. A. K. R. Handayani, L. Karjoko, and A. K. Jaelani, "Model Pelaksanaan Putusan Mahkamah Konstitusi yang Eksekutabilitas Dalam Pengujian Peraturan Perundang-Undangan di Indonesia," Bestuur, vol. 7, no. 1, pp. 36-46, 2019.

[17] F. U. Najicha, "Oil and Natural Gas Management Policy in Realizing Equal Energy in Indonesia," $J$. Hum. Rights, Cult. Leg. Syst., vol. 1, no. 2, pp. 71-79, 2021.

[18] S. D. Baranyanan, "Simplification of Law Regulations in Copyright Criminal Act Settlement," J. Hum. Rights, Cult. Leg. Syst., vol. 1, no. 2, pp. 8091, 2021. 